Tạp chí Khoa học và Công nghệ biển T11 (2011). Số 2. Tr 23 - 34

\title{
KẾT QUẢ ĐÁNH GIÁ TÁC ĐỘNG CỦA SỰ CỐ TRÀN DÂU ĐẾN TÀI NGUYÊN VÀ MÔI TRƯờNG BIỀN TỈNH BÀ RỊA VŨNG TÀU NĂM 2008
}

\author{
ĐỖ CÔNG THUNG, NGUYẼ̃N ĐĂNG NGẢI, LÊ THỊ THÚY \\ Viện Tài nguyên và Môi trường biển
}

\begin{abstract}
Tóm tắt: Tỉnh Bà Rịa - Vũng Tàu là một trong nhũng địa phưong bị ảnh hưởng nặng bởi nhiếm dầu trên biển do các vu tràn dầu gây ra. Vu tràn dầu tàu Đức Trí vào tháng 3/2008 đã gây hậu quả nghiêm trọng về môi truờng vùng ven biển của tỉnh này. Quy trình công nghệ đánh giá mức độ thiệt hại do ô nhiễm dầu đã được ứng dụng nhằm kiểm định mức độ thiệt hại do vu tràn dầu này. Kết quả nghiên cứu đã xác định không gian tác động rất lớn với chiều dài trên 60 km, tù Mũi Kê Gà đến Vũng Tàu, Bà Rịa và một phần huyện Cần Giờ của thành phố Hồ Chí Minh. Tràn dầu gây ô nhiễm môi truờng nước và trầm tích vuợt giới hạn tù 3 đến 16 lần, gây hậu quả làm chết các đối tương hải sản, giảm sản luợng đánh bắt và nuôi trồng. Các hệ sinh thái bãi cát, rùng ngập mặn đều bị ảnh huơong mạnh. Các hoạt động du lịch tháng 3/2008 của Vũng Tàu bị thiệt hại tới 60\% tổng doanh thu. Quả trình ứng dụng quy trình cũng cho thấy khả năng sử dụng quy trình công nghệ đánh giá thiệt hại ô nhiễm dầu trên biển Việt Nam đạt hiệu quả nhanh chóng và thuận tiện.
\end{abstract}

\section{MỞ ĐÀ̀U}

Dầu mỏ là một hỗn hợp các chất ở dạng lỏng, sánh không tan trong nước và nhẹ hơn nước. Thành phần của dầu mỏ bao gồm các hydrocacbon $(\mathrm{RH})$ có cấu trúc khác nhau và có thể phân thành 4 loại: các hydrocacbon mạch thẳng; hydrocacbon mạch vòng; hydrocacbon thơm; ngoài ra trong dầu mỏ còn các hợp chất oxy (các axit, xeton, rượu), các hợp chất chứa nitơ (indol, carbazol v.v.), hợp chất chứa lưu huỳnh (nhựa đường, Bitum) (Lưu Văn Diệu, 2002). Dầu có tỷ trọng nhỏ hơn nước, khi chảy loang trên mặt nước, dầu tạo thành váng và bị biến đổi về thành phần và tính chất. Dầu loang gây tác dụng xấu đến các hệ sinh thái và môi trường (GESAMP, 1977). Dầu tác động trực tiếp đến thế giới sinh vật trong nước khi chúng bám vào cơ thể sinh vật, ngăn cản quá trình hô hấp, trao đổi chất và sự di chuyển của sinh vật trong môi trường nước. ảnh hưởng gián tiếp của dầu loang đến sinh vật thông qua quá trình ngăn cản trao đổi oxy giữa nước với khí quyển tạo điều kiện tích tụ các khí độc hại như $\mathrm{H}_{2} \mathrm{~S}$, và $\mathrm{CH}_{4}$ làm tăng $\mathrm{pH}$. Dầu tràn, thường theo dòng chảy, dòng triều trôi dạt vào vùng biển ven bờ, bám vào đất đá, trên bãi triều, bám lên các kè đá, các bờ đảo làm mất mỹ quan, gây ra mùi khó chịu đối với du khách khi tham quan du lịch, tắm mát trên các khu vực danh lam thắng cảnh các bãi tắm. Do vậy, 
dầu tràn làm giảm doanh thu của ngành du lịch ở ven biển. Mặt khác, dầu tràn làm cho nguồn giống tôm cá bị ảnh hưởng thậm chí bị chết, dẫn đến làm giảm năng suất nuôi trồng và đánh bắt thuỷ sản ven biển. Dầu còn làm ảnh hưởng đến nghề khai thác muối từ nước biển do gây ra mùi vị khó chịu v.v. Hiện nay dầu loang là một trong những thảm hoạ môi trường do các vụ đắm tàu, các sự cố khai thác, vận chuyển dầu gây ra. Trong đó, hoạt động tàu thuyền trong cảng cũng là một trong những nguồn gây loang dầu quan trọng trên biển. Để có cơ sở khoa học đánh giá tác động của dầu tràn đến tài nguyên và môi trường biển, đề tài độc lập cấp nhà nước mã số ĐTĐL.2009 G/10 đã đề xuất "Quy trình công nghệ đánh giá thiệt hại ô nhiễm dầu trên biển Việt Nam”. Bài báo này giới thiệu kết quả ứng dụng quy trình này vào đánh giá tác động của vụ tràn dầu do tàu Đức trí gây ra vào ngày 2/3/2008 tai Bà Rịa - Vũng Tàu đến tài nguyên và môi trường biển kéo dài $60 \mathrm{~km}$ thuộc tỉnh Bà Rịa - Vũng Tàu.

\section{II. ĐỊA ĐIỂM, TÀI LIỆ, PHƯƠNG PHÁP NGHIÊN CỨU}

\section{1. Địa điểm và đối tượng khảo sát}

Địa điểm khảo sát: vùng bờ biển kéo dài khoảng $60 \mathrm{~km}$ từ ven bờ huyện Xuyên Mộc đến Long Đất, Vũng Tàu và Bà Rịa.

Đối tượng khảo sát: đã tổ chức tiến hành khảo sát tình hình tác động của dầu đến tài nguyên và môi trường khu vực ven biển tỉnh Bà Rịa - Vũng Tàu. Để có cơ sở đánh giá đầy đủ những tác động của tràn dầu đến hệ sinh thái (HST), chúng tôi đã tổ chức khảo sát đầy đủ về môi trường và các HST thái điển hình tại khu vực, gồm 3 HST cơ bản (Đỗ Công Thung, M. Sarti và nnk, 2004) dưới đây:

- Hệ sinh thái bãi cát biển: đã tổ chức khảo sát trên phạm vi gần $60 \mathrm{~km}$ chiều dài dọc vùng biển Long Đất, Xuyên Mộc, Vũng tàu và Bà Rịa.

- Hệ sinh thái rừng ngập mặn: Tập trung tại khu vực Hồ Tràm, Lagi, sông Thị Vải.

- Hệ sinh thái cửa sông: Tổ chức khảo sát tại 3 mặt cắt của sông Thị Vải.

\section{Các phương pháp điều tra khảo sát}

- Theo Quy phạm điều tra tổng hợp biển của Ủy ban Khoa học và Kỹ thuật Nhà nước năm 1981.

- Theo các hướng dẫn nghiên cứu của các tổ chức Quốc tế chuyên ngành bảo tồn và đa dạng sinh học như : hướng dẫn về nghiên cứu đa dạng sinh học của Wilkinson và Baker (1997). 
Bảng 1: Các tiêu chí và thông số đánh giá tác động của tràn dầu đến tài nguyên và môi trường biển (Đỗ Công Thung và nnk, 2010).

\begin{tabular}{|c|c|c|}
\hline TT & Các thông số QT & Định nghĩa \\
\hline $\mathrm{I}$ & \multicolumn{2}{|r|}{ Tiêu chí xác định nguồn gốc và chủng loại dầu } \\
\hline 1 & Nguồn gốc dầu tràn & $\begin{array}{c}\text { Là vị trí của đối tượng gây ra sự cố tràn dầu như tàu, khai thác mỏ } \\
\text { dầu .v.v. }\end{array}$ \\
\hline 2 & Chủng loại dầu tràn & Là dầu thô hay các sản phẩm của dầu dầu đã được lọc sạch. \\
\hline II & \multicolumn{2}{|c|}{ Tiêu chí xác định các yếu tố môi truò̀ng khi có sụ cố tràn dầu } \\
\hline 3 & Sóng, gió & Cấp độ sóng, gió (ước lượng) \\
\hline 4 & Thủy triều & $\begin{array}{c}\text { Mực giao động của thủy triều tại khu vực dự báo sẽ bị dầu tràn } \\
\text { ảnh hưởng (theo thủy triều Vũng tàu) }\end{array}$ \\
\hline III & \multicolumn{2}{|c|}{$\begin{array}{c}\text { Tiêu chí xác định quy mô ảnh hương của sụ cố tràn dầu đến các khu vục thuộc Bà Rịa - } \\
\text { Vũng Tàu }\end{array}$} \\
\hline 5 & $\begin{array}{l}\text { Vị trí và diện tích, độ } \\
\text { phủ các HST bị tác } \\
\text { động }\end{array}$ & $\begin{array}{l}\text { - Diện tích bị tác động : Quy mô không gian bị tác động } \\
\text { - Độ phủ: Tỷ lệ giữa diện tích bị che phủ bởi dầu thô so với diện } \\
\text { tích tự nhiên RNM, bãi cát biển. }\end{array}$ \\
\hline IV & \multicolumn{2}{|c|}{ Tiêu chí xác định ảnh huởng của dầu tràn đến môi truò̀ng sống của hệ sinh thái } \\
\hline 6 & Dầu trong nước & $\begin{array}{l}\text { Lượng dầu trong nước cao hơn so với hàm lượng dầu trước khi sự } \\
\text { cố tràn dầu xâyy ra, quan trắc bằng mắt các vệt dầu loang và thu } \\
\text { mẫu để phân tích. }\end{array}$ \\
\hline 7 & Dầu trong trầm tích & $\begin{array}{l}\text { Lượng dầu trong trầm tích cao hơn so với hàm lượng dầu trước khi } \\
\text { sự cố tràn dầu xẩy ra. Quan trắc bằng mắt khi đào phẫu diện. }\end{array}$ \\
\hline $\mathrm{V}$ & \multicolumn{2}{|c|}{$\begin{array}{l}\text { Tiêu chí xác định ảnh hưởng của dầu tràn làm biến đổi cấu trúc quần xã sinh vật trong } \\
\text { HST }\end{array}$} \\
\hline 8 & $\begin{array}{l}\text { Số lượng và thành phần } \\
\text { loài sinh vật bị chết }\end{array}$ & $\begin{array}{c}\text { Xác định số lượng các loài cỡ lớn như cá biển, hầu hà bị chết có } \\
\text { thể quan trắc được . Đếm ngay trên bãi triều và thu mẫu động vật } \\
\text { đáy để phân tích. }\end{array}$ \\
\hline VI & \multicolumn{2}{|c|}{ Tiêu chí đánh giá tác động của tràn dầu đến nguồn lọi hải sản/nuôi trồng } \\
\hline 9 & $\begin{array}{l}\text { Suy giảm sản lượng, } \\
\text { thành phần các nhóm } \\
\text { hải sản đánh bắt }\end{array}$ & $\begin{array}{l}\text { Xác định nhanh sản lượng đánh bắt của dân khu vực Vũng Tàu } \\
\text { trong thời kỳ dầu tràn. Phỏng vấn dân địa phương. }\end{array}$ \\
\hline 10 & $\begin{array}{l}\text { Suy giảm sản lượng } \\
\text { nuôi trồng hải sản }\end{array}$ & $\begin{array}{l}\text { Xác định số đầm nuôi có các đối tượng nuôi bị chết hoặc có các vết } \\
\text { dầu trong đầm nuôi. Quan trắc ngoài hiện trường và phỏng vấn dân } \\
\text { địa phương có đầm nuôi. }\end{array}$ \\
\hline VII & \multicolumn{2}{|c|}{ Tiêu chí đánh giá tác động của của tràn dầu các hoạt động kinh tế } \\
\hline 11 & $\begin{array}{l}\text { Giảm doanh thu từ các } \\
\text { hoạt động du lịch }\end{array}$ & $\begin{array}{l}\text { Khách du lịch bỏ phòng đã đặt hoặc hủy bỏ chuyến đi đến Bà Rịa - } \\
\text { Vũng Tàu .v.v. }\end{array}$ \\
\hline
\end{tabular}


- Phương pháp, kỹ thuật, thiết bị thu, phân tích mẫu thuỷ hoá (Môi trường nước). Chủ yếu dựa vào phương pháp thu và phân tích mẫu chuẩn của Mỹ công bố năm 1995 (APHA.AWWA.WEF,1995). Nội dung chủ yếu của phương pháp bao gồm: Mẫu nước được lấy ở các tầng khác nhau bằng máy lấy nước Van Dorn, bảo quản lạnh và đưa về phân tích trong phòng thí nghiệm theo các phương pháp cho từng yếu tố riêng biệt.

- Các thông số lựa chọn để đánh giá: Nhằm đánh giá nhanh tác động của dầu tràn đến tài nguyên và môi trường tỉnh Bà Rịa - Vũng Tàu, chúng tôi đã chọn 11 thông số thuộc 7 tiêu chí (bảng 1).

\section{Tài liệu}

- Tài liệu thu thập, phân tích đánh giá các nguồn sơ cấp, thứ cấp liên quan đến các hệ sinh thái tiêu biểu ven bờ Bà Rịa - Vũng Tàu.

- Tài liệu điều tra khảo sát chi tiết ở các khu vực trọng điểm được cập nhật, bổ sung các tư liệu về đa dạng sinh học, môi trường, các đe doạ đối với đa dạng sinh học các hệ sinh thái điển hình.

- Tài liệu phỏng vấn cộng đồng dân cư ven biển vùng nghiên cứu.

- Tài liệu đánh giá tình hình tác động của sự cố tràn dầu, cảnh báo địa phương các tác động và đề xuất phương án xử lý.

\section{KẾT QUẢ NGHIÊN CÚU}

\section{Giới thiệu tổng quan về sự cố tràn dầu tàu Đức Trí}

Hàng năm có khoảng 200 triệu tấn dầu từ Trung Đông được vận chuyển tới Nhật Bản và Hàn Quốc qua vùng biển ngoài khơi Việt Nam, đồng thời các hoạt động thăm dò và khai thác dầu khí ngoài khơi Việt Nam đang tăng lên hàng năm. Vì vậy Biển Đông đã trở thành một trong các địa điểm thăm dò và khai thác, vận chuyển dầu khí nhộn nhịp nhất Thế giới. Các hoạt động này thường kèm theo sự cố tràn dầu, gây ra tình trạng ô nhiễm nghiêm trọng ở vùng biển nước ta. Tỉnh Bà Rịa - Vũng Tàu là một trong những địa phương chịu ảnh hưởng nặng nề nhất của sự cố tràn dầu gây ra trên biển. Vụ tràn dầu tàu Đức Trí là một ví dụ điển hình. Tàu này chở 1.700 tấn dầu, do ông Nguyễn Văn Thiện làm thuyền trưởng và 14 thuyền viên khác, hành trình từ Thành phố Hồ Chí Minh (TP.HCM) đi Đà Nẵng. Tàu Đức Trí rời cảng Petechim (TP.HCM ) ngày 2 tháng 3 năm 2008 và gặp nạn ngay cùng ngày tại khu vực Mũi Né, Bình Thuận. Thời gian gặp nạn là vào lúc $22 \mathrm{~g}$ ngày 2 tháng 3 , khi đến vùng biển tỉnh Bình Thuận, cách thị xã La Gi khoảng 9 hải lý về hướng Đông Nam, do gặp sóng to và gió lớn nên tàu đã bị lật chìm. Trong số 
15 người trong thủy thủ đoàn, chỉ có một thuyền viên được tàu đánh cá BTH 1159 TS của tỉnh Bình Thuận vớt và chuyển vào Bệnh viện Bà Rịa cấp cứu, 14 người còn lại có thể đã không kịp rời tàu và bị kẹt trong tàu. Theo báo cáo nhanh của Ban chỉ huy phòng, chống lụt bão và tìm kiếm cứu nạn tỉnh Bình Thuận, sau khi tàu đắm, có khoảng 2 hải lý vuông dầu bị tràn ra ngoài với mức độ dày đặc và 6 hải lý vuông bị dầu tràn bao phủ với mức độ mỏng hơn. Gặp gió Đông Nam thổi mạnh, vết dầu tràn ra ngoài đã trôi về hướng biển Bà Rịa - Vũng Tàu và đến chiều ngày 4 tháng 3 năm 2008, vết dầu cách mũi Ba Kiệm (huyện Xuyên Mộc, tỉnh Bà Rịa - Vũng Tàu) khoảng 1 hải lý. Đến cuối giờ chiều ngày 6 tháng 3 , tàu Đức Trí đã bị đẩy trôi khỏi vị trí bị nạn 16 hải lý tới vị trí mới có tọa độ $10^{0}$ 29'39" Vĩ Bắc - $107^{0} 31^{\prime} 07^{\prime}$ " Kinh Đông và cách mũi Hồ Tràm (huyện Xuyên Mộc, tỉnh Bà Rịa Vũng Tàu) 4 hải lý về hướng Đông Bắc và bị lật úp hoàn toàn, hầu như không trôi dạt thêm. Ngày 7 tháng 3, tàu Đức Trí đã được neo cố định cách đất liền huyện Xuyên Mộc, tỉnh Bà Rịa-Vũng Tàu khoảng 1,5 hải lý. Cabin tàu đã bị mắc kẹt vào lớp bùn đáy biển. Theo khảo sát của Công ty Sao Mai, tàu Đức Trí đang chìm ở độ sâu khoảng 11,5 m, tàu gồm mười hầm chứa dầu, mỗi hầm chứa từ $132-288 \mathrm{~m}^{3}$; mực dầu từ 3,62 - 4,93 m. Ngày 7 tháng 3, trong vòng 12 giờ, vệt dầu loang kéo dài đến vùng biển Long Hải - Vũng Tàu. Chiều tối cùng ngày, dầu tiếp tục có dấu hiệu loang ra trên diện rộng. Sáng ngày 13 tháng 3 , dầu từ tàu chìm Đức Trí vẫn tiếp tục tràn vào Bãi Sau, trải dài từ khu du lịch Paradise đến mũi Nghinh Phong, trong đó khu du lịch Paradise có lượng dầu tràn vào nhiều nhất. Trước tình hình này, chính quyền địa phương đã phối hợp với nhân viên các khu du lịch tiến hành thu gom được hơn 7 tấn tạp chất dầu loang. Đến cuối giờ chiều cùng ngày, một ít lượng dầu vẫn tiếp tục dạt vào khu vực này. Tình trạng dầu loang đã khiến cho lượng khách du lịch đổ về thành phố biển giảm hẳn.

Tình hình ứng cứu sự cố tràn dầu cũng được tiến hành khẩn trương. Ngay sau khi nhận được thông tin tàu Đức Trí bị chìm, ngày 4 tháng 3 năm 2008, các lực lượng ứng cứu sự cố tràn dầu đã triển khai các biện pháp khẩn cấp ứng cứu sự cố tràn dầu. Sáng ngày 5 tháng 3, tàu SAR 413 của Trung tâm Phối hợp tìm kiếm cứu nạn Hàng hải Khu vực III đã có mặt tại hiện trường để thực hiện nhiệm vụ tìm kiếm, cứu nạn và khảo sát tình hình. Tàu Vũng Tàu 2003 và tàu Visal 08 đã có mặt tại hiện trường khẩn trương quây phao vớt dầu tràn. Ngoài 2 tàu trên còn có tàu HQ 606 của lực lượng Hải quân, tàu cao tốc của Biên phòng tỉnh Bình Thuận trợ giúp. Chiều ngày 6 tháng 3 , lực lượng cứu hộ đã tổ chức hút dầu tràn ra và cũng đã huy động Biên phòng, nhân dân khu vực có dầu tấp vào tìm cách thu gom đưa đi tiêu hủy. Riêng ngày 7 tháng 3, tại xã Phước Thuận, xã Bưng Riềng đã vớt được khoảng 30 tấn tạp chất dầu. Sáng ngày 9 tháng 3 , Thứ trưởng Bộ Tài nguyên và Môi trường đã nhấn mạnh đến hai ưu tiên: lấy thi thể nạn nhân và không cho tràn dầu. Có hai phương án đặt ra: hoặc là khoan thân tàu, hút dầu; hoặc mở nắp hầm tàu, bơm khí vào 
cho tàu nổi lên. Đến ngày 19 tháng 3 năm 2008 đã tiến hành hút dầu từ các khoang chứa của tàu Đức Trí thành công.

\section{Tác động của sự cố tràn dầu tàu Đức Trí đến tài nguyên và môi trường Bà Rịa Vũng Tàu}

\section{Xác định nguồn gốc dầu tràn}

Nguồn gốc dầu tràn đã nhanh chóng được xác định là do tàu Đức Trí chở 1.700 tấn dầu, do ông Nguyễn Văn Thiện làm thuyền trưởng và 14 thuyền viên khác, hành trình từ TP.HCM đi Đà Nẵng. Tàu Đức Trí rời cảng Petechim (Thành phố Hồ Chí Minh) ngày 2 tháng 3 năm 2008 và gặp nạn ngay cùng ngày tại khu vực Mũi Né, Bình Thuận. Thời gian gặp nạn là vào lúc $22 \mathrm{~g}$ ngày 2 tháng 3 , khi đến vùng biển tỉnh Bình Thuận, cách thị xã La Gi khoảng 9 hải lý về hướng Đông Nam. Đến chiều ngày 6 tháng 3, tàu Đức Trí đã bị đẩy trôi khỏi vị trí bị nạn 16 hải lý tới vị trí mới có tọa độ $10^{0} 29^{\prime} 39^{\prime}$ ” Vĩ Bắc - $107^{0} 31^{\prime}$ '07” Kinh Đông và cách mũi Hồ Tràm (huyện Xuyên Mộc, tỉnh Bà Rịa - Vũng Tàu) 4 hải lý về hướng Đông Bắc và bị lật úp hoàn toàn và được cố định tại đây (hình 1).

\section{Chủng loại dầu tràn}

Đó là dầu thô FO. Lượng dầu tràn ra ngoài ban đầu phủ dày khoảng 2 - 3 hải lý vuông và 6 hải lý vuông dầu tràn ra với mức độ mỏng hơn. Gặp gió Đông Nam thổi mạnh, vết dầu tràn ra ngoài đã trôi về hướng biển Bà Rịa - Vũng Tàu và đến chiều ngày 4 tháng 3 năm 2008, vết dầu cách mũi Ba Kiệm (huyện Xuyên Mộc, tỉnh Bà Rịa - Vũng Tàu) khoảng 1 hải lý và sau đó trôi vào các bãi triều. Dầu tiếp tục tràn ra, từ các khoang chứa dầu và tấp vào các bãi triều ven biển với tổng số dầu thu gom 100 tấn.

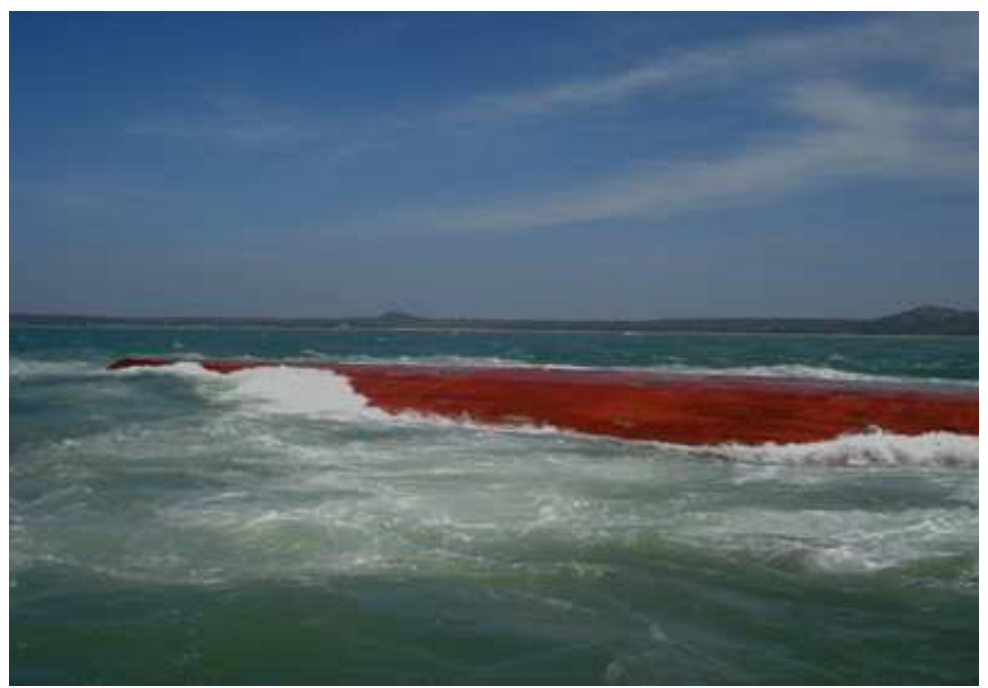

Hình 1: Ảnh tàu Đức Trí bị đắm (theo http://www.xaluan.com) 
Sóng, gió

Gió Đông - Nam cấp 6 đến cấp 7 , sóng cấp 4 đến cấp 5 vì vậy dầu tràn sẽ bị đẩy từ vùng biển Bình Thuận về Bà Rịa - Vũng Tàu

\section{Thủy triều}

Cao nhất trên $4 \mathrm{~m}$ và thấp nhất $0,4 \mathrm{~m}$, tạo điều kiện thuận lợi cho dầu tràn tấp vào các bãi triều và đầm nuôi

\section{Các hệ sinh thái bị tác động}

- Hệ sinh thái vùng triều bãi cát: Tác động của dầu lên hệ sinh thái bãi cát được thể hiện rõ nhất. Khoảng trên 100 tấn dầu đã được thu gom từ Xuyên Mộc qua Long Đất đến Vũng Tàu, chạy dài trên $60 \mathrm{~km}$. Các điểm bị dầu trôi dạt vào nhiều là Hồ Tràm (hình 2). Dân ở đây đã được huy động dùng quốc, xẻng hót dầu cho vào bao để đưa đi xử lý. Theo thông báo của dân địa phương thì họ đã thu gom được khoảng 60 tấn dầu ở khu vực này. Dân tại bãi biển Phước Hải (Long Đất) cũng thu được trên 30 tấn dầu. Các bãi tắm Vũng Tàu cũng bị dầu tấn công. Các nhà hàng, khách sạn và cơ quan, quân đội được huy động tham gia thu gom dầu suốt từ Xuyên Mộc đến Vũng Tàu (hình 2) .

- Hệ sinh thái rừng ngập mặn: Rừng ngập mặn $(\mathrm{RNM})$ nằm trong đường bao ven biển ít bị ảnh hưởng. Một phần không lớn RNM nằm ở các cửa lạch từ Xuyên Mộc về đến Vũng Tàu đều có hiện tượng vệt dầu bao thân cây hoặc lá cây, phần dưới gốc cây. Khu vực RNM Cần Giờ thành phố Hồ Chí Minh cũng đã bị ảnh hưởng. Theo điều tra nhân dân cho biết vào lúc 23 giờ ngày 8 tháng 3 , hai tàu hải đội và một tàu kiểm ngư, các thuyền dân đã phát hiện nhiều vết dầu $\mathrm{FO}$ loang rải rác cách biển Cần Giờ khoảng $1 \mathrm{~km}$ và khu vực Vàm Tắc Xuất, Dinh Bà từ $1 \mathrm{~km}$ đến $3 \mathrm{~km}$. Sáng ngày 9 tháng 3 , lực lượng ứng cứu tại thị trấn Cần Thạnh đã đi thu nhặt một tấn rác thấm dầu, cho vào bao đưa lên bờ kè, chuyển đến bãi rác Long Hòa để xử lý. Dọc biển Cần Thạnh, phát hiện những váng dầu vón thành cục bằng đầu ngón tay và nhiều vết dầu loang kéo dài hơn $2 \mathrm{~km}$. Huyện đã nhanh chóng thả gần $100 \mathrm{~m}$ phao kéo thấm dọc bờ biển để đưa dầu vào xử lý.

- Hệ sinh thái đầm nuôi: Chúng tôi đã khảo sát hệ thống đầm nuôi, chạy từ Xuyên Mộc về đến Vũng Tàu bằng cách quan sát váng dầu, cục dầu còn lại và phỏng vấn chủ đầm thì đều không phát hiện thấy hiện tượng tôm cá chết trong đầm, trong suốt thời gian dầu bắt đầu tràn. Lý do là các chủ đầm đã kịp thời đóng cống ngăn không cho dầu vào đầm, vì vậy họ đã tránh được thiệt hại do dầu gây ra. Tuy nhiên, các bãi nuôi nghêu ở bãi triều đã bị ảnh hưởng như nghêu chết, thịt nghêu có mùi dầu. Đặc biệt hàng ngàn ha nuôi nghêu sò của huyện Cần Giờ được đặt trong tình trạng nguy hiểm. 


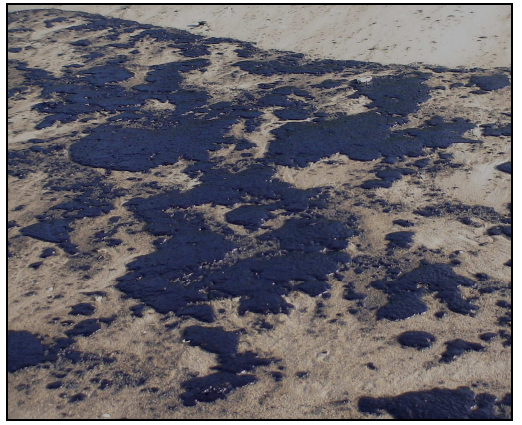

(1)

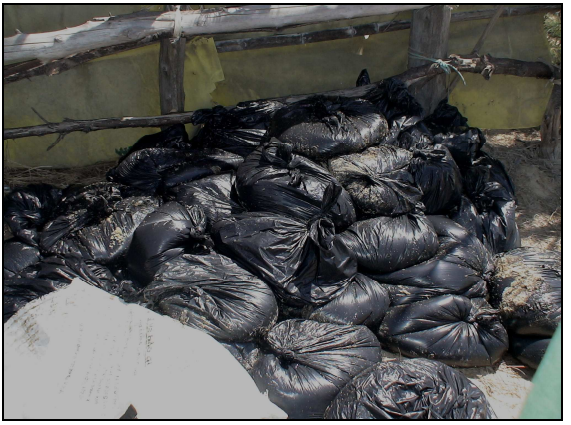

(2)

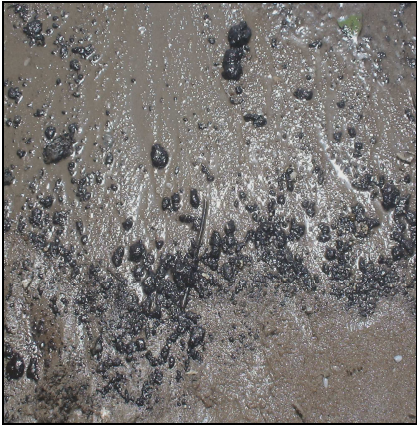

(3)

Hình 2: Ảnh hưởng của dầu đến HST bãi cát dọc từ Xuyên Mộc đến Vũng Tàu (1. Bãi cát Hồ Tràm huyện Xuyên Mộc; 2.Bao đựng dầu Xã Phuớc Hải huyện Long Đất; 3. Bãi sau Vũng tàu)

\section{Ảnh hưởng của dầu đến chất lượng nước và trầm tích}

- Dầu trong nước: Khi mới tràn dầu, khoảng 3 hải lý vuông bị phủ bởi lớp váng dầu dày đặc và 6 đến 7 hải lý vuông lớp váng dầu mỏng hơn. Do khuếch tán của dầu mà trong nước biển các khu vực từ Xuyên Mộc đến Vũng Tàu đều có các váng dầu trôi trên mặt biển. Đặc biệt khu vực Hồ Tràm nước biến màu từ xanh sang màu xám đen (hình 3).

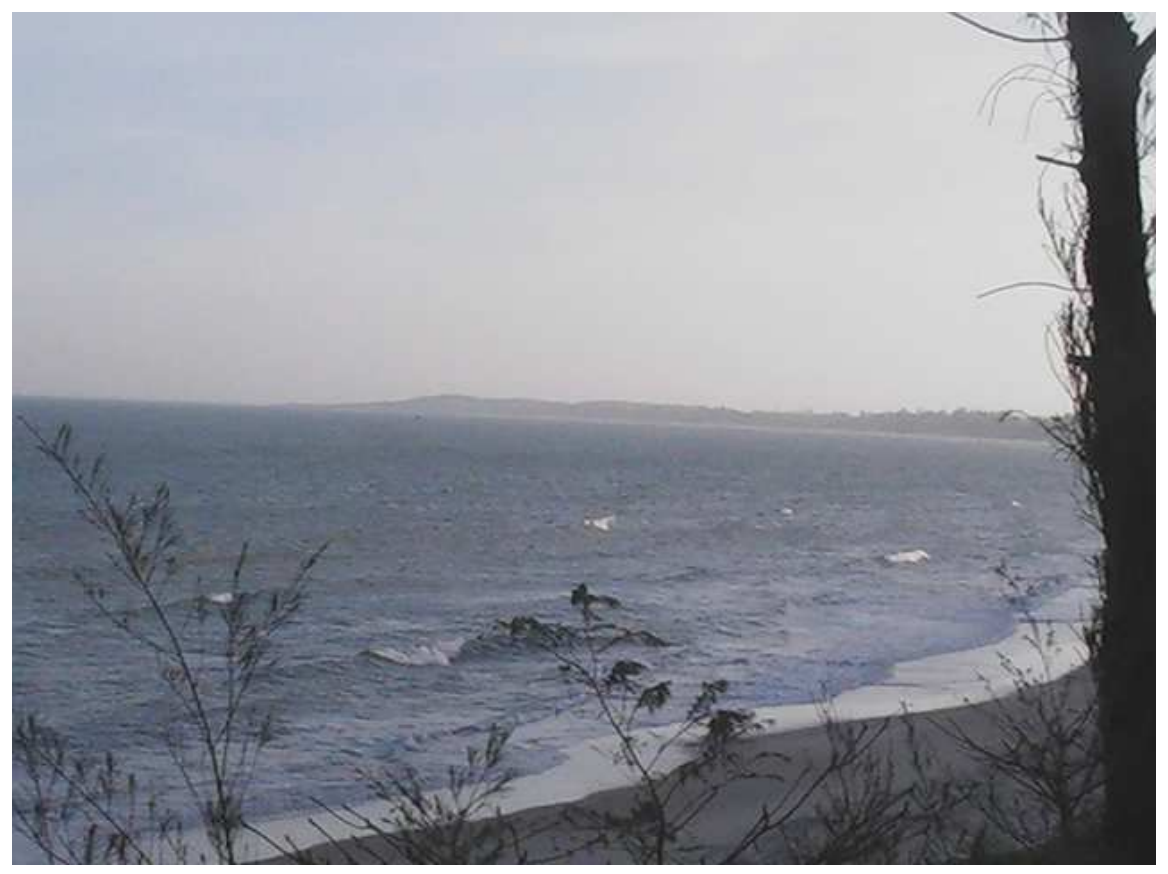

Hình 3: Nước khu Hồ Chàm bị dầu làm biến màu 
Sau 8 ngày sự cố tràn dầu xẩy ra, hàm lượng dầu trong nước ở khu vực bãi tắm Vũng Tàu vẫn đạt từ 0,37 đến $1,69 \mathrm{mg} / \mathrm{L}$, cao hơn 3 đến 16 lần so với giới hạn cho phép (Tiêu chuẩn Việt Nam, 2005), (bảng 2).

Bảng 2: Hàm lượng dầu và muối dinh dưỡng trong nước tại bãi tắm Vũng Tàu thu ngày 10/3/2008

\begin{tabular}{|c|c|c|c|c|c|}
\hline $\begin{array}{c}\text { Trạm thu } \\
\text { mẫu }\end{array}$ & $\begin{array}{c}\mathrm{N}-\mathrm{NO}_{2}^{-} \\
(\mu \mathrm{g} / \mathrm{L})\end{array}$ & $\begin{array}{c}\mathrm{N}-\mathrm{NO}_{3}^{-} \\
(\mu \mathrm{g} / \mathrm{L})\end{array}$ & $\begin{array}{c}\mathrm{N}-\mathrm{NH}_{4}^{+} \\
(\mu \mathrm{g} / \mathrm{L})\end{array}$ & $\begin{array}{c}\mathbf{P}-\mathbf{P O}_{4}{ }^{3-} \\
(\mu \mathrm{g} / \mathrm{L})\end{array}$ & $\begin{array}{c}\text { Dầu } \\
\text { (mg/L) }\end{array}$ \\
\hline 1 & 10.91 & 131.0 & 83.5 & 27.35 & 1.58 \\
\hline 2 & 8.73 & 110.7 & 71.2 & 20.56 & 0.83 \\
\hline 3 & 12.00 & 119.8 & 97.6 & 19.83 & 0.37 \\
\hline 4 & 7.56 & 96.5 & 69.5 & 21.79 & 1.69 \\
\hline \multicolumn{3}{|c|}{ GHCP (Tiêu chuẩn Việt Nam, 2005) } & & & $0,1 \mathrm{mg} / 1$ \\
\hline
\end{tabular}

- Dầu trong trầm tích: Mặc dầu đã đựoc thu gom, nhưng dầu vẫn phủ khá nhiều trên các bãi cát ở dạng các hạt nhỏ, tròn hoặc dẹt. Chúng tôi đã tiến hành đào phẫu diện trên bãi cát ở bãi tắm cho thấy ở độ sâu $0,5 \mathrm{~m}$ vẫn có dầu phân bố. Khối lượng dầu thu được từ $0,5-1,2 \mathrm{~kg} / \mathrm{m}^{2}$ diện tích bề mặt bãi.

\section{Tác động của dầu đến nguồn lợi hải sản và nuôi trồng}

- Tác động của dầu đến nguồn lợi hải sản: Các quan sát trên bãi biển, vào các buổi sáng sớm lúc từ 3 đến 4 h00 sáng từ ngày 10 đến ngày 13 tháng 3 năm 2008 tại bãi sau của Vũng Tàu, đã phát hiện một số loài hải sản quan trọng bị chết trôi dạt vào bờ như Mực ống (Loligo sp) 3 - 5 con/ 100 m dài bãi biển, cá đối (Mugil sp) 1- 2 con chết/100 m dài. Trong suốt thời gian nước biển bị ô nhiễm, dân khai thác ven bờ đều không thể ra khơi. Khi phỏng vấn người dân họ cho rằng có ra khơi cũng không bắt được gì. Những đối tượng bắt được cũng chỉ là cá tạp và sẽ có mùi dầu, không thể bán được.

- Tác động của dầu đến nuôi trồng: Các hộ nuôi nghêu (Meretrix lyrata) khu vực này đều bị ảnh hưởng vì ngao có hiện tượng chết hàng loạt và có mùi dầu không tiêu thụ được. Các đầm nuôi có cống nải tốt thì lạc quan hơn, do đóng cống nên không có dầu vào đầm, vì vậy tôm, cua, cá trong các ao nuôi không thấy bị ảnh hưởng.

Tác động của dầu đến du lịch

Có lẽ tác động này được thể hiện rất rõ. Các nhà nghỉ trong dịp này bị khách trả 
phòng khá nhiều. Khi hỏi các chủ khách sạn họ cho biết, dầu trên các bãi cát đã làm khách du lịch sợ hãi và hủy bỏ chuyến du lịch ngày 8 tháng 3 năm 2008 ở Vũng Tàu. Theo dân địa phương, mọi năm trong dịp này, hầu hết khách sạn đều có khách trọ, thậm chí không còn chỗ cho những người đến muộn. Nhưng dịp này chỉ có khoảng $1 / 3$ số lượng khách sạn, nhà nghỉ là có khách. Như vậy tổng thiệt hại do dầu tràn Đức Trí đối với ngành du lịch là làm giảm khoảng $60 \%$ thu nhập.

\section{Đánh giá mức độ thiệt hại do vụ tràn dầu của tàu Đức Trí}

Các kết quả quan trắc và thông tin thu được, chúng tôi cho rằng vụ tràn dầu Đức Trí là hết sức nghiêm trọng. Không gian tác động rất lớn từ Mũi Kê Gà đến Vũng Tàu, Bà Rịa và một phần huyện Cần Giờ của thành phố Hồ Chí Minh. Các đối tượng bị tác động tập trung chính vào làm ô nhiễm môi trường nước, trầm tích gây hậu quả cho ngành du lịch, nuôi trồng thủy sản ở bãi triều. Cũng cần nhấn mạnh rằng, việc khắc phục sự cố tràn dầu của các địa phương, các ban ngành chức năng là rất tích cực. Kết quả là đã hạn chế tác động xấu rất nhiều. Một phần lớn dầu tràn đã được thu gom và đưa đi xử lý. Các đầm nuôi cũng kịp thời ngăn không cho dầu tràn vào đầm, đã khắc phục được sự chết hàng loạt của các đối tượng nuôi. Các bãi triều, bãi cát du lịch đã nhanh chóng được làm sạch, tạo điều kiện thuận lợi cho các hoạt động của địa phương trở lại bình thường.

\section{Các giải pháp}

Sau khi nghiên cứu quy mô của tràn dầu và tác động của nó đến tài nguyên và môi trường biển có thể đưa ra nhận xét và giải pháp khắc phục như sau:

- Quy mô của vụ tràn dầu là rất lớn và gây thiệt hại về người và tàu, nhưng do có sự khắc phục sự cố nhanh nên mức độ làm chết các đối tượng nuôi, nguồn lợi đã được hạn chế đáng kể.

- Môi trường nước và trầm tích vẫn tiếp tục bị ô nhiễm vì vậy cần có các giải pháp khắc phục sự cố lâu dài.

- Các giải pháp cần tiếp tục như: tiếp tục dọn sạch dầu còn lại trên các bãi biển; vận động dân khu vực nuôi dùng các phương pháp phao chắn ngăn cho dầu không tràn vào khu vực nuôi; tiếp tục theo dõi mức độ ô nhiễm dầu trong nước biển để thông báo cho dân ra khơi đánh cá và bằng mọi cách hút hết số dầu còn nằm trong khoang tàu Đức Trí ra ngoài.

\section{KẾT LUẬN}

- Vụ tràn dầu tàu Đức Trí đã tác động trên quy mô rộng lớn, ảnh hưởng đến môi trường nước, trầm tích. Tác động của ô nhiễm dầu đã làm chết nguồn lợi hải sản, ảnh 
hưởng tới các hoạt động du lịch, nuôi trồng của địa phương. Nhưng do có sự phối hợp tốt giữa các cơ quan liên quan đến ứng cứu sự cố tràn dầu, nên đã hạn chế tác động đáng kể.

- Các biện pháp xử lý như hút dầu, ngăn dầu, quây phao vớt dầu và xử lý thủ công như hót dầu bằng cuốc, xẻng, đóng cống khi có sự cố tràn dầu đều mang lại hiệu quả tốt, nhưng không thể làm sạch được dầu trong nước và trong trầm tích.

- Phương pháp đánh giá tác động của dầu tràn bằng bộ thông số cụ thể sẽ cho kết quả tốt để xác định hậu quả của ô nhiễm dầu ở vùng biển Việt Nam.

- Để có thể đòi bồi thường thiệt hại do ô nhiễm dầu gây ra trên vùng biển Việt Nam đòi hỏi phải có phương pháp lượng giá các thiệt hại kinh tế do sự cố dầu tràn đối với các hệ sinh thái biển.

\section{TÀI LIỆU THAM KHẢO}

1. APHA.AWWA.WEF, 1995. Standard Methods for the examination of water and waste water. Pub. Washington, DC 20005.

2. Lưu Văn Diệu, 2002. Dầu tràn trên biển. Kỷ yếu hội thảo "Quản lý môi trường cảng tại Việt Nam”, biên tập Luc Hens, Trần Đình Lân. Báo cáo kỹ thuật, lưu trữ tại Viện Tài nguyên và Môi trường biển.

3. GESAMP (Joint Group of Experts on the Scientific Aspects of Marine Pollution) IMCO/FAO/UNESCO/WMO/WHO/IAEA/UN, 1977. Report and Studies. No 6 - Impact of Oil on the Marine Environment.

4. Đỗ Công Thung và nnk, 2010. Quy trình công nghệ đánh giá thiệt hại ô nhiễm dầu trên biển Việt Nam

5. Đỗ Công Thung, M. Sarti và nnk, 2004. Bảo tồn đa dạng sinh học dải ven bờ Việt Nam. NXB. Đại học Quốc gia.

6. Tiêu chuẩn Việt Nam, 2005. Tuyển tập 31 tiêu chuẩn Việt Nam về môi trường bắt buộc áp dụng.

7. Wilkinson English, S., C. \& Baker, V., 1997. Survey Manual for Tropical Marine Resources 2nd Edition. Australian Institute of Marine Science. 390pp. 


\title{
THE RESULTS EVALUATING IMPACTS OF OIL SPILL TO ENVIRONMENTS AND MARINE RESOURCES IN BA RIA - VUNG TAU PROVINCE IN 2008
}

\author{
DO CONG THUNG, NGUYEN DANG NGAI, LE THI THUY
}

\begin{abstract}
Summary: The Ba Ria - Vung Tau province is one of the most locations strong impacted by oil spil. The oil spill Duc Tri Ship on 3/2008 caused very strong bad impact to marine environment and resources at this locality. The technical process evaluating impacts of oil spill to marine environment and resources was used to test level of loss caused by Duc Tri oil spill. The results show that the spatial area impacted is very large with the long coastline over $60 \mathrm{~km}$, from Ke Ga cape to Vung Tau, Ba Ria and a part of the Can Gio district of Ho Chi Minh City. The oil spill has caused oil pollution of marine water and sediments at 3 to 16 times comparing with Vietnamese standards. The consequence of the oil spill was loosed fisheries and decreasing fishery and Marin culture production. The beaches, mangrove ecosystems were impacted strongly. The tourism at 3/2008 on Vung Tau was loosed 60\%. The study also can identify good capacity to use this technical Process in the evaluating impacts of oil spill on the Vietnam Sea.
\end{abstract}

Ngày nhận bài: 24 - 3 - 2011

Ngưòi nhận xét: PGS. TS. Trần Đức Thạnh 